\title{
Análise da modalidade regime diferenciado de contratação nas licitações do DNIT
}

\author{
Karine da Rocha Alves \\ Departamento Nacional de Infraestrutura de Transportes (Dnit), Porto Alegre, RS, Brasil

\section{Taís de Andrade} \\ Universidade Federal de Santa Maria (UFMS), Santa Maria, RS, Brasil

\section{Luciano Moises Sippert Santarem} \\ Departamento Nacional de Infraestrutura de Transportes (Dnit), Porto Alegre, RS, Brasil
}

\section{Resumo}

Desde 2012 o Departamento Nacional de Infraestrutura de Transportes (DNIT) vem utilizando o Regime Diferenciado de Contratação (RDC) e pesquisas estão sendo realizadas para verificar a efetividade dos seus objetivos. A proposta deste artigo consiste na avaliação das contribuições relacionadas à eficiência na aplicação do RDC nas obras de infraestrutura de transportes do DNIT. Para tanto, foram verificados prazos de licitações, descontos ofertados e o número de concorrentes de 91 lotes de obras de RDC, cujos editais de licitação foram divulgados no período de 2015 a 2017, nas diversas unidades regionais do DNIT e na sua sede em Brasília. Ao comparar os valores obtidos com os encontrados na bibliografia, observa-se que nas licitações de RDC houve uma redução nos prazos médios dos certames e um aumento no desconto médio ofertado, sendo mais evidente quando os orçamentos não são sigilosos. Os resultados da pesquisa contribuem como referência aos legisladores que pretendem aprimorar ou popularizar o RDC, bem como aos gestores do DNIT na condução dos processos licitatórios.

Palavras chave: Regime Diferenciado de Contratação (RDC), licitações de obras do DNIT, eficiência na gestão pública 


\section{Análisis del modo régimen diferenciado de contratación en las licitaciones del DNIT}

Desde 2012, el Departamento Nacional de Infraestructura de Transporte (DNIT) ha estado utilizando el Régimen de Contratación Diferencial (RDC) y se están realizando investigaciones para verificar la efectividad de sus objetivos. El propósito de este documento es evaluar las contribuciones relacionadas con la eficiencia de la aplicación de la RDC en las obras de infraestructura de transporte de DNIT. Con este fin, se verificaron los plazos de licitación, los descuentos ofrecidos y el número de licitadores de 91 lotes de obras de la RDC, cuyos documentos de licitación se publicaron de 2015 a 2017, en las diversas unidades regionales de DNIT y en su sede en Brasilia. Al comparar los valores obtenidos con los encontrados en la bibliografía, se observa que en las ofertas de la RDC hubo una reducción en los términos promedio de las ofertas y un aumento en el descuento promedio ofrecido, siendo más evidente cuando los presupuestos no son confidenciales. Los resultados de la encuesta contribuyen como referencia a los legisladores que desean mejorar o popularizar la RDC, así como a los gerentes de DNIT en la conducción de los procesos de licitación.

Palabras clave: Régimen Diferenciado de Contratación (RDC), licitaciones de obras del DNIT, eficiencia en la gestión pública

\section{Analysis of the differentiated contracting regime modality in DNIT bidding}

Since 2012 the National Department of Transport Infrastructure (DNIT) has been using the Differential Contracting Regime (RDC) and research is being conducted to verify the effectiveness of its objectives. The purpose of this paper is to evaluate the contributions related to the efficiency of the application of the RDC in DNIT transport infrastructure works. To this end, bidding deadlines, discounts offered and the number of bidders from 91 lots of RDC works were verified, whose bidding documents were published from 2015 to 2017, in the various regional units of DNIT and in its headquarters in Brasilia. When comparing the values obtained with those found in the bibliography, it is observed that in the RDC bids there was a reduction in the average terms of the bids and an increase in the average discount offered, being more evident when the budgets are not confidential. The survey results contribute as a reference to legislators wishing to improve or popularize the RDC, as well as DNIT managers in the conduct of bidding processes.

Keywords: Differentiated Contracting Regime (RDC), bidding DNIT works, efficiency in public management 


\section{Introdução}

A mídia às vezes divulga condutas adotadas por algumas entidades públicas quanto às suas contratações ou compras que não condizem com o interesse público, que resultam em despesas excedentes ou processos fracassados. Entre os instrumentos de controle do Estado, existem as leis que regem as licitações no Brasil, elaboradas com base no artigo 37 da Constituição Federal de 1988, que determinou que nenhuma obra, serviço, compra ou alienação sejam contratados sem que haja processo prévio de licitação pública, exceto nas situações ressalvadas pela legislação. Essas leis buscam assegurar, em última instância, a proposta mais vantajosa para a administração pública, procurando dessa forma maior controle no gasto dos recursos públicos (MALMEGRIN, 2010).

Para muitos gestores públicos, a Lei de Licitações no 8.666/1993, que perdura há anos, e a Lei do Pregão nำ10.520/2002, são obsoletas, inadequadas às atuais necessidades da administração pública, muito rígidas nas formalidades e possibilitam um excesso de recursos administrativos pelos licitantes. Os gestores anseiam por grandes mudanças na legislação, a fim de buscar maior eficiência nas contratações (BRANCO JUNIOR, 2013).

O modelo de Regime Diferenciado de Contratação (RDC) foi instituído pela Lei no 12.462/2011 inicialmente para ser aplicado aos contratos necessários à realização da Copa das Confederações Fifa de 2013, da Copa do Mundo Fifa de 2014, Olimpíadas e Paraolimpíadas de 2016. O modelo aumentou sua abrangência incluindo a sua aplicação, entre outras, às ações integrantes do Programa de Aceleração do Crescimento (PAC). Sendo assim, o Departamento Nacional de Infraestrutura de Transportes (DNIT) pôde contratar obras de infraestrutura de transportes neste novo regime, que em vários aspectos se diferencia da Lei de Licitações no 8.666/1993, como por exemplo na sua opção integrada, que não obriga que exista projeto básico na fase de licitação.

De acordo com a lei que criou o RDC, este foi instituído com os objetivos de ampliar a eficiência nas contratações públicas e a competitividade entre os licitantes; bem como promover a troca de experiências e tecnologias em busca da melhor relação entre custos e benefícios para o setor público; incentivar a inovação tecnológica; e assegurar tratamento isonômico entre os licitantes e a seleção da proposta mais vantajosa para a administração pública (BRASIL, 2011b). 
Desde que foi criado o novo regime de contratações, houve a extensão de sua aplicação a diversas áreas, podendo o RDC futuramente vir a ser o modelo usual pela administração pública no lugar da Lei no 8.666/1993. Devido a essa tendência, existe a necessidade de se observar como os gestores públicos estão administrando o RDC, quais as dificuldades enfrentadas, suas vantagens e desvantagens para que se sustente a sua continuidade. Elaborar uma pesquisa com esse tema tem o propósito de analisar a utilização desse novo regime de contratação na administração pública na área de infraestrutura de transportes.

Para tanto, o presente estudo propõe como problema de pesquisa o seguinte questionamento: “ Quais são as contribuições relacionadas à eficiência na utilização do RDC para as licitações de obras de infraestrutura de transportes, sob responsabilidade do DNIT? "

O objetivo principal da pesquisa consiste na identificação das contribuições relacionadas à eficiência na aplicação do RDC nas obras de infraestrutura de transportes do DNIT. A avaliação proposta consiste em comparar os prazos de duração das licitações, número de participantes e descontos obtidos no período entre 2015-2017, com licitações do órgão anteriores a 2012, data de adoção ao RDC pelo DNIT. Os objetivos específicos consistem em: i) realizar análise documental com resultados de prazos, descontos e número de participantes em pesquisas relacionadas a licitações do DNIT, anteriormente ao RDC, isto é, antes de 2012; ii) identificar os prazos de licitação, descontos ofertados e número de participantes em amostra de editais de RDC de obras do DNIT no período de 2015-2017; e iii) relacionar as observações e recomendações relevantes, obtidas através das decisões, acórdãos e relatórios de auditorias de órgãos de controle externo e interno.

Os resultados da pesquisa podem servir como elementos de contribuição para a administração do DNIT, assim como referência para outros órgãos da administração pública na tomada de decisão em adotar o RDC em suas contratações. Considerando que o RDC em relação às licitações previstas pela Lei no 8.666/1993 tem período menor de aplicação, esse é um fator motivador para a pesquisa. A experiência na administração pública e o acesso às informações no DNIT em função do cargo em exercício por parte da maioria dos autores favoreceram em alcançar os objetivos propostos.

O artigo foi estruturado em 5 seções, sendo apresentada na seção 1 a introdução, que apresenta o assunto objeto do estudo, a identificação do problema, a relevância da 
pesquisa e os objetivos principal e específicos. A seção 2 contempla o referencial teórico que descreve a origem do RDC, seus objetivos, princípios e diretrizes, suas vantagens e aplicação do regime pelo DNIT. Na seção 3 é exposta a metodologia aplicada na pesquisa. Na seção 4 é apresentada a análise dos resultados alinhados com os objetivos propostos. A seção 5 aborda as conclusões e, por fim, na sequência, listam-se as referências que foram utilizadas.

\section{Referencial teórico}

\subsection{A origem do Regime Diferenciado de Contratação (RDC)}

As contratações de obras, serviços e aquisição de bens públicos no Brasil, obrigatoriamente, devem ser precedidas por licitações conforme estabelecido pela Constituição Federal de 1988 no seu artigo 37, inciso XXI, cuja regulamentação foi dada pela Lei no 8.666, de 1993, que é denominada na bibliografia pesquisada como Lei Geral de Licitações (LGL).

No Brasil, em meados da década de 1990, iniciava-se a reforma do Estado burocrático para o modelo gerencial, em que um dos princípios incorporados é o da eficiência, que foi inserido no caput do artigo 37 da Constituição através da emenda constitucional $n^{\circ}$ 19/1998. Bergue (2010) citando Lacombe (2004) define eficiência como:

[...] a capacidade de minimizar o uso de recursos para alcançar as metas definidas, ou seja, é a capacidade de otimizar o uso dos recursos, e seria medida pela relação entre recursos aplicados e o produto final obtido (BERGUE, 2010, pág. 39).

A LGL forjada num modelo burocrático era constantemente criticada por causar morosidade nas licitações e, consequentemente, ser pouco eficiente, não proporcionando muitas vezes a proposta mais vantajosa para a administração (BAETA, 2013). No cenário regido pelo modelo gerencial, houve o surgimento de novas leis e modelos de licitações, como a Lei no 8.987/1995, que dispõe sobre o regime de concessão e permissão da prestação de serviços públicos previsto no art. 175 da Constituição Federal, a Lei no 10.520/2002, que instituiu, 
no âmbito da União, estados, Distrito Federal e municípios, nos termos do art. 37, inciso XXI, da Constituição Federal, modalidade de licitação denominada pregão, para aquisição de bens e serviços comuns, e a Lei no 11.079/2004, que institui normas gerais para licitação e contratação de parceria público-privada no âmbito da administração pública.

A Lei no 10.520/2002 traz uma nova modalidade de licitação antes não prevista na LGL, o pregão, que proporciona à administração pública reduzir as formalidades e aumentar a celeridade dos procedimentos licitatórios, mas somente podendo ser utilizado para a aquisição de bens e serviços comuns. O pregão, tanto na versão presencial como na eletrônica, diferencia-se das demais modalidades da LGL principalmente por realizar a inversão das etapas na fase externa da licitação, havendo primeiramente o julgamento das propostas de preço e, depois, a análise dos documentos de habilitação (BREYER, 2013).

Quando o Brasil foi escolhido para sediar a Copa do Mundo de 2014 e os Jogos Olímpicos e Paraolímpicos de 2016, o Estado sabia que teria pela frente uma corrida contra o tempo para cumprir um cronograma de obras e que não estão caracterizadas por serviços comuns para a aplicação da modalidade pregão. Diante desse desafio, o Poder Executivo tinha urgência em estabelecer novas regras para as licitações. Provavelmente optando por um caminho mais curto e menos desgastante, o governo resolveu criar uma legislação específica, limitada nos âmbitos objetivo, subjetivo, temporal e espacial, ao invés de optar em revisar e reformar a atual LGL.

Após a tramitação de três medidas provisórias no Congresso Nacional, somente na quarta tentativa o Poder Executivo obteve êxito na aprovação do RDC com a Medida Provisória (MPV) n 527 de 2011, originando a Lei $n^{\circ} 12.462$ de 2011, que abrangeu as obras de infraestrutura e serviços em aeroportos das capitais dos estados da Federação distantes até $350 \mathrm{~km}$ das sedes dos mesmos eventos esportivos (BAETA, 2013).

Desde então a aplicação do RDC foi sendo ampliada através de novas legislações, sendo possível visualizar a evolução dos atos normativos pertinentes através do Quadro 01, que está organizado na ordem cronológica das ocorrências. 
Quadro 01 | Evolução da legislação de RDC

\begin{tabular}{|c|c|c|}
\hline Legislação & Data & Abrangência \\
\hline Lei 12.462 & 04 de agosto de 2011 & $\begin{array}{l}\text { Estabelece o RDC para a Copa do Mundo de } \\
2014 \text { e para as Olimpíadas de } 2016 \text { (art. 1o, } \\
\text { e II). Estende-se ainda às obras em aeroportos } \\
\text { das capitais dos Estados da Federação distantes } \\
\text { até } 350 \mathrm{~km} \text { das cidades sede (art. 1ํ, II). }\end{array}$ \\
\hline Decreto no 7.581 & 11 de novembro de 2011 & $\begin{array}{l}\text { Regulamenta o RDC, de que trata a Lei } \mathrm{n} \text { - } \\
\text { 12.462. }\end{array}$ \\
\hline Lei no 12.688 & 18 de julho de 2012 & $\begin{array}{l}\text { Conversão da Medida Provisória no } 559 \text {, de } \\
2012 \text { que estende o RDC às ações integrantes } \\
\text { do PAC (art. 28). }\end{array}$ \\
\hline Lei no 12.722 & 03 de outubro de 2012 & $\begin{array}{l}\text { Além das hipóteses previstas no caput, o RDC } \\
\text { também é aplicável às licitações e contratos } \\
\text { necessários à realização de obras e serviços de } \\
\text { engenharia no âmbito dos sistemas públicos de } \\
\text { ensino. }\end{array}$ \\
\hline Lei no 12.745 & 19 de dezembro de 2012 & $\begin{array}{l}\text { Aplicável às obras e serviços de engenharia no } \\
\text { âmbito do Sistema Único de Saúde - SUS. }\end{array}$ \\
\hline Lei no 12.833 & 20 de junho de 2013 & $\begin{array}{l}\text { Aplicável às obras e serviços dos aeroportos } \\
\text { regionais. }\end{array}$ \\
\hline Decreto $\mathrm{n}-8.080$ & 20 de agosto de 2013 & Altera o Decreto no 7.581. \\
\hline Lei no 12.873 & 24 de outubro de 2013 & $\begin{array}{l}\text { Autoriza a Companhia Nacional de } \\
\text { Abastecimento - Conab, a utilizar o Regime } \\
\text { Diferenciado de Contratações Públicas - RDC. }\end{array}$ \\
\hline Lei no 12.980 & 28 de maio de 2014 & $\begin{array}{l}\text { Aplicável à obras e serviços de engenharia } \\
\text { para construção, ampliação e reforma de } \\
\text { estabelecimentos penais e unidades de } \\
\text { atendimento socioeducativo e outras alterações. }\end{array}$ \\
\hline Lei no 12.983 & 03 de junho de 2014 & $\begin{array}{l}\text { Execução de ações de resposta e recuperação } \\
\text { nas áreas atingidas por desastre e sobre o } \\
\text { Fundo Especial para Calamidades Públicas } \\
\text { e inclui a utilização do Regime Diferenciado } \\
\text { de Contratações Públicas - RDC e dá outras } \\
\text { providências. }\end{array}$ \\
\hline
\end{tabular}




\begin{tabular}{|c|c|c|}
\hline Legislação & Data & Abrangência \\
\hline Lei $n^{\circ} 13.190$ & 19 de novembro de 2015 & $\begin{array}{l}\text { Ampliou o uso do RDC nas obras e serviços de } \\
\text { engenhariaparaconstrução, ampliaçãoe reforma } \\
\text { e administração de estabelecimentos penais e } \\
\text { de unidades de atendimento socioeducativo, } \\
\text { das ações no âmbito da segurança pública, das } \\
\text { obras e serviços de engenharia, relacionadas a } \\
\text { melhorias na mobilidade urbana ou ampliação } \\
\text { de infraestrutura logística e dos contratos de } \\
\text { locação de bens móveis e imóveis, nos quais o } \\
\text { locador realiza prévia aquisição, construção ou } \\
\text { reforma substancial, com ou sem aparelhamento } \\
\text { de bens, por si mesmo ou por terceiros, do bem } \\
\text { especificado pela administração. }\end{array}$ \\
\hline Lei $n^{\circ} 13.243$ & 11 de janeiro de 2016 & $\begin{array}{l}\text { Permitiu a utilização do RDC em ações de } \\
\text { estímulos ao desenvolvimento científico, à } \\
\text { pesquisa, à capacitação científica e tecnológica } \\
\text { e à inovação. }\end{array}$ \\
\hline
\end{tabular}

Fonte: elaboração própria.

\subsubsection{Dos objetivos, princípios e diretrizes do RDC}

O parágrafo primeiro do artigo $1^{\circ}$ da Lei $\mathrm{n}$ ㅇ $12.462 / 2011$ apresenta os objetivos do RDC:

I-ampliar a eficiência nas contratações públicas e a competividade entre os licitantes;

II - promover a troca de experiências e tecnologias em busca da melhor relação entre custos e benefícios para o setor público;

III - incentivar a inovação tecnológica; e

IV - assegurar tratamento isonômico entre os licitantes e a seleção da proposta mais vantajosa para a administração pública.

O uso do RDC não é obrigatório para as obras e serviços que se enquadram entre os casos aplicáveis previstos na legislação, entretanto, a opção pelo RDC deve estar expressa no edital e somente se poderá recorrer das exigências da LGL nos casos previstos na Lei no $12.462 / 2011$. 
No que se refere aos princípios do RDC, nota-se que se mantêm os mesmos da LGL, acrescidos de dois novos princípios: da eficiência e da economicidade. Estes princípios constitucionais não só buscam a melhor relação custo benefício, não só pelo menor preço ofertado, mas por outros fatores de cunho econômico verificáveis no decorrer da execução contratual.

Para a execução das licitações no novo regime de RDC, o artigo 4을 da Lei $\mathrm{n}$ 은 12.462/2011 apresenta as diretrizes a serem observadas nas licitações e contratos de RDC:

I. padronização do objeto da contratação relativamente às especificações técnicas e de desempenho e, quando for o caso, às condições de manutenção, assistência técnica e de garantia oferecidas;

II. padronização de instrumentos convocatórios e minutas de contratos, previamente aprovados pelo órgão jurídico competente;

III. busca da maior vantagem para a administração pública, considerando custos e benefícios, diretos e indiretos, de natureza econômica, social ou ambiental, inclusive os relativos à manutenção, ao desfazimento de bens e resíduos, ao índice de depreciação econômica e a outros fatores de igual relevância;

IV. condições de aquisição, de seguros, de garantias e de pagamento compatíveis com as condições do setor privado, inclusive mediante pagamento de remuneração variável conforme desempenho, na forma do art. 10;

V. utilização, sempre que possível, nas planilhas de custos constantes das propostas oferecidas pelos licitantes, de mão de obra, materiais, tecnologias e matériasprimas existentes no local da execução, conservação e operação do bem, serviço ou obra, desde que não se produzam prejuízos à eficiência na execução do respectivo objeto e que seja respeitado o limite do orçamento estimado para a contratação; e

VI. parcelamento do objeto, visando à ampla participação de licitantes, sem perda de economia de escala.

VII. ampla publicidade, em sítio eletrônico, de todas as fases e procedimentos do processo de licitação, assim como dos contratos, respeitado o art. $6^{\circ}$ desta Lei.

A padronização de editais, especificações e contratos previstos neste artigo citado da lei reforça a proposta de agilidade nos processos licitatórios e contratuais. 


\subsection{A polêmica em torno da constitucionalidade do RDC}

A opção do governo em tramitar uma nova legislação que mudaria a forma de licitar através de Medida Provisória em vez de ter encaminhado um projeto de lei ao Congresso, e que levou quatro anos até a formulação da Lei no 12.462/2011, sendo controverso a um caráter de urgência, já geraria polêmicas acerca da instituição do regime.

Apesar da adoção do RDC por diversos órgãos de diferentes esferas públicas, no Supremo Tribunal Federal há duas ações de inconstitucionalidade contra esse regime que ainda estão sendo analisadas por aquela corte. Uma delas, a ADI n 4.645, foi ajuizada por um grupo de partidos políticos, e a outra, a ADI $n^{\circ} 4.655$, ajuizada pelo Procurador Geral da República.

Em ambas ações o principal questionamento sobre a constitucionalidade do RDC refere-se aos vícios formais na tramitação da MPV $n^{\circ} 527$. Essa medida não tratava de licitações e contratos, e sim sobre a organização da Presidência da República e dos ministérios, a criação da Secretaria de Aviação Civil, a alteração das Leis da Anac e da Infraero, a criação de cargos em comissão e a contratação de controladores de tráfego aéreo (BAETA, 2013).

Entretanto, no projeto de Lei de conversão da medida provisória, houve inclusão de matéria estranha àquela que originalmente tratava a medida provisória, qual seja, o RDC. A Resolução ${ }^{\circ} 1$, de 1989-CN, estabelece expressamente em seu art. $4^{\circ}$ ser vedada a apresentação de emendas que versem sobre matéria estranha àquela tratada na medida provisória.

As ADIs n 4.645 e 4.655 também questionam a inconstitucionalidade material, pois os arts. 1 e 65 delegam ao Executivo a escolha do regime jurídico aplicável com base em critérios subjetivos. Os autores das ações defendem que a Lei de RDC concede ao administrador margem de discricionariedade incompatível com os arts. 22, inciso XXVII, e 37, caput e inciso XXI, ambos da Constituição Federal, transferindo uma competência normativa ao Poder Executivo, que deve ser do Poder Legislativo (RoDRIGUES, 2016).

Segundo Baeta (2013) apud Dal Pozzo (2012), com as alterações da Lei no 12.462/2011 ampliando a abrangência do RDC, pode-se encontrar outras possíveis 
inconstitucionalidades. O motivo seria que, na redação original da Lei, o RDC tinha vigência determinada no tempo, uma vez que condicionava a realização dos eventos esportivos que aconteceriam no Brasil no ano de 2016. Entretanto a Lei sofreu alterações que possibilitaram ações, obras e serviços de engenharia com prazo indeterminado para encerramento.

\subsection{Vantagens trazidas pela lei de RDC}

Se um dos objetivos do RDC na sua criação era trazer eficiência aos processos licitatórios, espera-se que traga em sua legislação novidades para atingir esse objetivo diferentes naqueles contidos na LGL. Portanto, revisando a Lei nำ12.462/2011 e seus dispositivos legais de regulamentação e bibliografia pertinente, destacam-se no Quadro 02 algumas inovações oriundas do novo regime de licitação, que podem contribuir e alterar o andamento das licitações de obras e serviços de engenharia. Algumas das mudanças como o orçamento sigiloso e inversão de fases não são novidades em licitações, pois são aplicáveis na modalidade pregão, que não abrange todos os serviços de engenharia nem obras.

Quadro 02 | Inovações da Lei n 12.462/2011

Item de inovação na Lei $n^{\circ}$
12.462/2011
Prazos mínimos entre divulgação
da licitação e o recebimento das
propostas

Inversão da fase de habilitação pela a de apresentação das propostas de preços

\section{Descrição}

Para os casos de obras, principalmente as rodoviárias, que na maioria dos casos em função do valor devem ser realizadas na modalidade concorrência pela LGL, esse prazo seria de 30 dias. Se fosse realizada por RDC com critério de julgamento pelo menor preço ou pelo maior desconto esse prazo se reduziria a 15 dias.

Se tratando de RDC, como regra geral a habilitação será realizada depois da abertura e julgamento das propostas de preços e da realização da fase de lances. A Lei 8.666/93 estabelece que todos os concorrentes estejam habilitados, e para isso a Administração deve analisar os documentos de todos os participantes da licitação, sem saber se a proposta de preço será a mais vantajosa. De acordo com Celestino (2012) a referida inversão de fases encurta sensivelmente o prazo do certame. 


\section{Item de inovação na Lei $\mathrm{n}^{\circ}$ $12.462 / 2011$}

Modo de disputa aberto

Regime de execução do tipo integrada

Remuneração variável

Fase recursal única

\section{Descrição}

Ao contrário da $L G L$, o RDC pode ser em regime aberto onde os licitantes apresentarão suas ofertas por meio de lances públicos e sucessivos, crescentes ou decrescentes, conforme o critério de julgamento adotado. Mas a Lei no 12.462/2011 também permite a adoção do regime fechado quando as propostas apresentadas pelos licitantes serão sigilosas até a data e hora designadas para que sejam divulgadas (BAETA, 2013). $O$ art. 16 da Lei de RDC ainda prevê a utilização dos dois modos de disputa combinados, regulamentado pelo art. 24 do Decreto 7.581/2011.

Esse regime permite que uma mesma licitação tenha em seu objeto a execução dos projetos básico e executivo e ainda a execução das respetivas obras. A LGL não permite que obras sejam licitadas sem projeto básico e contratantes distintos sejam responsáveis pelos projetos e obras. No regime integrado a Administração deve disponibilizar no edital o anteprojeto de engenharia que contemple os documentos técnicos destinados a possibilitar a caracterização da obra ou serviço. Esse regime encurta o tempo que se perderia licitando e/ou se elaborando o projeto de forma separada para que depois se licite as obras (LOLI; MeLLo; Rojo, 2017; BRANCO JUNIOR, 2013).

O novo regime de licitações apresenta a possibilidade de remuneração variável na contratação das obras e serviços, inclusive de engenharia, nos valores pactuados no contrato administrativo em razão do desempenho e agilidade da contratada. Para tanto, as metas, padrões de qualidade, critérios de sustentabilidade ambiental, prazo de entrega e limites das variações devem estar definidos no edital do certame (CORRALO; CARDOSO, 2015).

A fase de recurso no RDC somente poderá ocorrer após a habilitação do vencedor, no prazo de 5 (cinco) dias úteis. Os participantes poderão interpor recurso após o julgamento das propostas ou lances e à habilitação do vencedor unicamente num mesmo período, reduzindo os prazos de recursos utilizados na LGL. Contudo se houver a inversão de fases no RDC, cada uma delas terá seu prazo de recurso em períodos distintos. 
Item de inovação na Lei $\mathrm{n}^{\circ}$ $12.462 / 2011$

Orçamento sigiloso

Negociação de condições mais vantajosas com os licitantes

Pré-qualificação

\section{Descrição}

Pela Lei $n^{\circ} 12.462 / 2011$ quando o orçamento não constar no instrumento convocatório, ele terá caráter sigiloso, sendo divulgado apenas e imediatamente após o encerramento da licitação. Somente poderão ter acesso ao orçamento sigiloso antes ou durante a licitação os órgãos de controle interno e externo da administração pública. Oliveira e Freitas (2011) afirmam que o orçamento sigiloso sempre foi defendido por parcela da doutrina, especialmente para evitar que a divulgação do orçamento influenciasse a elevação dos valores constantes das propostas e a formação de cartel entre os licitantes, já que, sem a ciência do preço estimado pela Administração, fica mais difícil de fazer combinações entre concorrentes. Os mesmos autores ressalvam que a Organização para Cooperação e Desenvolvimento Econômico (OCDE), também recomenda o uso do orçamento sigiloso como pode ser conferida no Guidelines for fighting bid rigging in public procurement (Diretrizes para combater o conluio entre concorrentes em contratações públicas).

Há duas maneiras de negociação previstas no regulamento do RDC: uma na fase de julgamento da licitação quando a proposta do primeiro classificado estiver acima do orçamento estimado e a outra após o término da fase recursal, durante a fase de encerramento do procedimento licitatório. Para Paim (2015, pag. 42, apud Justen Filho,2012, pag. 278) o RDC apresenta como vantagem econômica a utilização da negociação, que inexiste na LGL, por estipular a disciplina e criar o ambiente para que haja competição entre o maior número de interessados aptos a serem contratados.

A pré-qualificação no RDC difere da prevista na LGL, por ser uma pré-qualificação permanente, para a inscrição dos eventuais interessados e não se refere a um caso concreto considerado (Celestino, 2012). Baeta (2013) especifica que a préqualificação em RDC pode ser utilizada em número indefinido de licitações, podendo ser subjetiva (pré-qualificação do fornecedor ou objetiva (pré-qualificação do produto ou bem). A Administração somente poderá realizar licitações restritas aos pré-qualificados nas condições do Decreto $n^{\circ} 7.581 / 2011$. A pré-qualificação fixa um direito de participação na licitação em favor dos que foram nela identificados, definindo-se um padrão de qualidade mínima a ser atendida na competição a ser realizada. A Administração optando por esse procedimento poderá estabelecer os seus padrões sem haver a necessidade de identificação dos recursos necessários que financiará os seus empreendimentos, otimizando o processo de habilitação quando o certame de fato ocorrer.

Fonte: elaboração própria. 


\subsection{O RDC no DNIT}

O Departamento Nacional de Infraestrutura de Transportes (DNIT), com sede em Brasília, Distrito Federal, é uma autarquia federal vinculada ao Ministério dos Transportes, criada pela Lei no 10.233, de 5 de junho de 2001. A legislação reestruturou o sistema de transportes rodoviário, aquaviário e ferroviário do Brasil, extinguindo o antigo Departamento Nacional de Estradas de Rodagem (DNER). Atualmente, possui 25 unidades administrativas regionais - as superintendências, e 8 administrações hidroviárias.

A autarquia tem por objetivo implementar a política de infraestrutura do Sistema Federal de Viação, compreendendo sua operação, manutenção, restauração ou reposição, adequação de capacidade e ampliação, mediante construção de novas vias e terminais. Os recursos para a execução das obras são da União, ou seja, o órgão é gestor e executor, sob a jurisdição do Ministério dos Transportes, das vias navegáveis, ferrovias e rodovias federais, instalações de vias de transbordo e de interface intermodal e instalações portuárias fluviais e lacustres (DEPARTAMENTO NACIONAL DE INFRAESTRUTURA DE TRANSPORTES, 2018).

Na pesquisa bibliográfica, identifica-se que o DNIT não foi um dos primeiros órgãos a utilizar o RDC, tendo em vista que a autarquia é uma das principais executoras do PAC, e que essa abrangência não constava na primeira versão da legislação. Em agosto de 2012 o DNIT iniciou a sua experiência em licitar na modalidade RDC, tornando-se pioneiro na versão eletrônica que aumenta a competividade nas licitações, possibilitando a participação de empresas de todo país (DNIT, 2012).

Apesar de pouco tempo ainda de utilização do RDC em relação à $L G L$, encontramse na bibliografia pesquisada trabalhos a respeito do desempenho das licitações do DNIT, como o Acórdão 306/2017 - TCU - Plenário, que apresentou para a amostra analisada, por aquela auditoria, que o RDC no regime integrado foi o que apresentou os piores resultados comparado aos demais regimes de contratação pela LGL e RDC não integrado no que tange ao número de participantes, aos descontos obtidos no preço contratado, aos prazos despendidos nos procedimentos licitatórios e ao grau de insucesso das licitações. Mesmo com indícios que os procedimentos licitatórios da contratação integrada no DNIT seja menos eficiente que as contratações pela LGL, o artigo de Caldeira et al. (2017) constata que, entre os 10 órgãos/entidades da administração pública federal pesquisadas 
pelos autores, o DNIT foi o único que alocou e precificou o risco dos empreendimentos licitatórios na modalidade contratação integrada.

Durante a pesquisa documental, outras pesquisas, com abrangência similar à que será estudada neste artigo, foram encontradas, como a de Lima (2010) que pesquisou sobre os descontos de obras do DNIT em licitações no regime da LGL, no período de 2002 - 2009. Branco Junior (2013), no período de 2001 - 2013, analisou as licitações de obras do DNIT e da Infraero, regidas pela LGL e RDC. Rosinha (2013) observou o período por fase das licitações de RDC do DNIT em editais de 2012 - 2013. Breyer (2013) selecionou 20 editais do DNIT no período de 2009 a 2012 regidos pela LGL e 20 de RDC de 2012, e comparou os prazos desde a fase de divulgação do edital até sua homologação em cada conjunto. $\mathrm{O}$ trabalho mais atual com editais de obras similares à amostra analisada de RDC no DNIT com resultados de prazos, descontos e número de concorrentes, foi o desenvolvido pela CGU - Ministério da Transparência e Controladoria-Geral da União através do relatório de auditoria divulgado em fevereiro de 2017, com editais de 2012 a 2014 (CONTROLADORIA GERAL DA UNIÃO, 2017).

\section{Método de estudo}

A presente pesquisa caracteriza-se como um estudo de abordagem quantitativa, e quanto ao seu objetivo, pode-se considerar descritiva. Como grande parte das pesquisas em administração está orientada para a investigação de problemas relacionados às práticas administrativas, e quanto a sua natureza pode ser classificada como pesquisa aplicada.

Com a intenção de cumprir um dos objetivos específicos da pesquisa, identificaramse os editais de RDC do DNIT da sua sede e superintendências regionais que foram publicados desde o início de 2015 e o final de 2017. Na limitação do período se considerou a pesquisa realizada pela CGU (2017) que teve como objetivo avaliar os resultados de adoção do regime RDC com ênfase na contratação integrada no DNIT, em período anterior ao pesquisado.

Esses dados foram obtidos através de consultas ao sítio eletrônico do DNIT e no portal de compras do Governo Federal - Comprasnet. Os casos com dados omissos ou 
incompletos foram esclarecidos através de consulta por correio eletrônico aos gestores responsáveis pelas licitações. A população levantada é composta de 121 editais de RDC, todos eletrônicos, sendo desse total 28 da sede em Brasília e 93 das superintendências regionais. Além dos editais que se referiam à execução de obras, também foram considerados serviços de recuperação de rodovias e de obras-de-arte especial, e portuários como dragagem e derrocamento.

Foram consideradas para a amostra somente as licitações de execução de obras homologadas até o dia $1 \% 06 / 2018$, e desconsideradas aquelas que foram revogadas, fracassadas, canceladas ou anuladas, bem como os editais de serviços de supervisão, gerenciamento, estudos e projetos, gestão ambiental e aquisição de licença de softwares, restando para análise uma amostra de 82 editais, que resultaram em 91 lotes de obras, pois em alguns editais há mais de um lote de obra. Os lotes de obras estão distribuídos entre a sede e as regionais, em que se constata que $13 \%$ foram conduzidos pela sede e $87 \%$ pelas superintendências regionais.

As informações de prazo de duração das licitações, número de participantes, regime, valores estimados pela administração e valores homologados foram organizados em planilhas eletrônicas e gráficos para a análise documental, utilizando-se as ferramentas e funções estatísticas do software Excel.

O período de prazo de duração das licitações foi calculado em dias, a partir da data de recebimento das propostas no sistema Comprasnet de maneira eletrônica e a data de homologação. O desconto considerado na proposta homologada foi calculado em \% em relação ao preço estimado pela administração, isto é, o quociente entre a diferença do valor estimado pela administração e o valor homologado pelo valor por ela estimado.

Os dados de prazos, descontos e número de participantes de editais do DNIT pela LGL foram apurados em resultados de pesquisas realizadas por outros autores durante a revisão bibliográfica, para a comparação com os dados coletados dos editais de RDC. 


\section{Análise dos resultados}

Quanto às características da amostra, verifica-se que, do total dos 91 lotes, 12 foram geridos pela sede do DNIT e 79 ficaram sob responsabilidade das superintendências regionais, representando respectivamente $13 \%$ e $87 \%$. Dos editais da sede, $92 \%$ eram de contratação integrada e $8 \%$ de empreitada por preço unitário. Nas superintendências, $65 \%$ eram de contratação integrada, $19 \%$ de empreitada por preço global e $16 \%$ de empreitada por preço unitário. As licitações com orçamentos sigilosos representam 56\%, e não sigilosos $44 \%$ da amostra.

Mesmo que o art. $6^{\circ}$ da Lei no 12.462/2011 exija que o orçamento previamente estimado pela administração se torne público após o encerramento do certame, a Superintendência do Rio Grande do Sul não havia divulgado o valor real orçado dos editais sobre a sua gestão. O período de prazo de licitação e número de concorrentes de todos os editais do Rio Grande do Sul puderam ser utilizados, entretanto, quanto aos descontos, somente foi possível a utilização de 1 (um) edital da regional devido à falta da informação do valor orçado pela administração até o momento da análise dos resultados.

A análise dos resultados está organizada em três subseções, que tratam de comparar cada item dos processos licitatórios: prazos, descontos e número de concorrentes, extraídos da amostra de editais de RDC com dados encontrados na bibliografia de editais pela LGL.

\subsection{Prazos da licitação}

Considerando a data inicial quando o certame foi aberto no sítio eletrônico do Governo Federal - Comprasnet - aos interessados para realizarem lances de valores, e o encerramento na data de homologação do edital, obteve-se que a média desse prazo foi de aproximadamente 78 dias, entretanto os valores são bem dispersos, conforme demonstrado na Tabela 01 . O menor prazo foi de 6 dias, em um edital de Santa Catarina, e o maior prazo é de um edital do Rio Grande do Sul, que durou 499 dias. Rosinha (2013) encontrou em sua pesquisa em editais do DNIT de RDC entre 2012-2013, para a mesma 
fase em análise, a média de 76 dias, corroborando com o valor encontrado.

Apurando os prazos de licitações pela LGL e pelo RDC, o trabalho de Breyer (2013) encontrou uma redução no prazo de licitação em torno de $40 \%$ quando adotado o RDC. Branco Junior (2013), nos editais que analisou, encontrou uma redução de $30 \%$ para o mesmo prazo nos editais de RDC.

Em uma comparação análoga utilizando os prazos encontrados por Breyer (2013) para editais pela LGL de obras do DNIT e os dados da amostra analisada em editais de RDC, obtém-se uma redução em torno de $10 \%$. Essa redução poderia ser maior, em torno de $26 \%$, se o DNIT encurtasse o prazo entre a publicação do edital e a abertura do certame, pois a média de 35 dias é maior que o prazo mínimo exigido pela legislação de RDC, Lei no $12.462 / 2011$, de 15 dias consecutivos para obras e serviços de engenharia com critério de julgamento de menor preço ou maior desconto, mesmo critério da amostra analisada.

Tabela 01 | Prazos de licitação em RDCs do DNIT (2015 - 2017)

\begin{tabular}{cccccc} 
Unidade & \multicolumn{3}{c}{ Prazo entre a abertura do certame e a homologação } \\
gestora & $\begin{array}{c}\text { Quant. } \\
\text { editais }\end{array}$ & Média & $\begin{array}{c}\text { Desvio } \\
\text { padrão }\end{array}$ & Mínimo & Máximo \\
\hline Sede & 12 & 80,8 & 40,0 & 43,0 & 153,0 \\
\hline AL & 4 & 74,0 & 37,4 & 46,0 & 129,0 \\
\hline AM & 12 & 132,1 & 40,5 & 83,0 & 210,0 \\
\hline BA & 5 & 62,2 & 34,6 & 18,0 & 102,0 \\
\hline CE & 3 & 24,7 & 15,3 & 8,0 & 38,0 \\
\hline GO/DF & 13 & 36,4 & 26,5 & 7,0 & 77,0 \\
\hline MA & 3 & 65,7 & 78,2 & 19,0 & 156,0 \\
\hline MG & 1 & $64,0 *$ & $*$ & $*$ & $*$ \\
\hline MS & 5 & 61,4 & 42,4 & 21,0 & 106,0 \\
\hline MT & 6 & 103,8 & 78,0 & 33,0 & 211,0 \\
\hline PA & 1 & $87,0 *$ & $*$ & $*$ & $*$ \\
\hline PB & 1 & $20,0 *$ & $*$ & $*$ & $*$ \\
\hline PR & 1 & $218,0 *$ & $*$ & $*$ & $*$ \\
\hline
\end{tabular}




\begin{tabular}{cccccc}
\hline $\begin{array}{c}\text { Unidade } \\
\text { gestora }\end{array}$ & $\begin{array}{l}\text { Quant. } \\
\text { editais }\end{array}$ & Média & $\begin{array}{c}\text { Prazo entre a abertura do certame e a homologação } \\
\text { Dadrão }\end{array}$ & Mínimo & Máximo \\
\hline RJ & 7 & 37,4 & 13,9 & 20,0 & 53,0 \\
\hline RN & 1 & $167,0^{*}$ & $*$ & $*$ & $*$ \\
\hline RO/AC & 2 & 47,0 & 7,1 & 42,0 & 52,0 \\
\hline RR & 1 & $103,0 *$ & $*$ & $*$ & $*$ \\
\hline RS & 3 & 226,0 & 238,4 & 59,0 & 499,0 \\
\hline SC & 3 & 52,3 & 59,2 & 6,0 & 119,0 \\
\hline TO & 7 & 64,0 & 44,8 & 13,0 & 138,0 \\
\hline Total & 91 & 78,4 & 68,7 & 6,0 & 499,0 \\
\hline
\end{tabular}

Fonte: elaboração própria.

Nota: * Apenas 1 edital disponível para análise.

\subsection{Descontos}

A maneira pela qual ocorreram os descontos por unidade gestora do DNIT que realizou a licitação, pode ser verificada na Tabela 02. A média de desconto para a amostra completa encontrada foi de $13,7 \%$, sendo o maior desconto de $45,2 \%$ referente ao edital do Rio de Janeiro de reconstrução/restabilização de talude de orçamento não sigiloso. A CGU (2017) apurou uma média de desconto em editais de RDC de 9,18\%.

Os descontos para os editais da amostra analisada por Branco Junior (2013) não apresentaram diferenças significativas entre aqueles regrados pela $L G L$ e os de RDC, variaram de $10 \%$ para $13,5 \%$ em média, respectivamente. O mesmo não ocorreu para as obras no regime de contratação integrada, nas quais os descontos chegaram ao valor de $2,9 \%$. 
Tabela 02 | Análise do comportamento dos descontos em RDCs (2015 - 2017)

\begin{tabular}{|c|c|c|c|c|c|c|c|c|c|c|c|c|c|}
\hline \multirow{2}{*}{$\begin{array}{l}\text { Unidade } \\
\text { gestora }\end{array}$} & \multirow{2}{*}{$\begin{array}{l}\text { Quant. } \\
\text { editais }\end{array}$} & \multicolumn{4}{|c|}{$\begin{array}{l}\text { Desconto para amostra } \\
\text { completa (\%) }\end{array}$} & \multicolumn{4}{|c|}{$\begin{array}{c}\text { Desconto } \mathrm{p} / \text { orçamento } \\
\text { sigiloso (\%) }\end{array}$} & \multicolumn{4}{|c|}{$\begin{array}{c}\text { Desconto } \mathrm{p} / \text { orçamento não } \\
\text { sigiloso }(\%)\end{array}$} \\
\hline & & Média & $\begin{array}{l}\text { Desvio } \\
\text { padrão }\end{array}$ & Mín. & Máx. & Média & $\begin{array}{l}\text { Desvio } \\
\text { padrão }\end{array}$ & Mín. & Máx. & Média & $\begin{array}{l}\text { Desvio } \\
\text { padrão }\end{array}$ & Mín. & Máx. \\
\hline Sede & 12 & 7,3 & 6,4 & 2,0 & 22,7 & 4,0 & 1,7 & 2,3 & 6,9 & 11,9 & 8,0 & 2,0 & 22,7 \\
\hline$A L$ & 4 & 20,7 & 6,9 & 10,6 & 25,1 & - & - & - & - & 20,7 & 6,9 & 10,6 & 25,1 \\
\hline AM & 12 & 3,5 & 5,1 & 0,0 & 17,3 & 3,5 & 5,1 & 0,0 & 17,3 & - & - & - & - \\
\hline BA & 5 & 11,1 & 6,8 & 2,0 & 17,6 & 9,6 & 6,7 & 2,0 & 17,6 & $17,5^{*}$ & $*$ & * & $*$ \\
\hline CE & 3 & 6,0 & 10,4 & 0,0 & 18,0 & - & - & - & - & 6,0 & 10,4 & 0,0 & 18,0 \\
\hline GO/DF & 13 & 13,5 & 7,7 & 0,1 & 28,7 & 11,6 & 6,4 & 1,5 & 19,3 & 15,2 & 8,8 & 0,1 & 28,7 \\
\hline MA & 3 & 23,5 & 11,0 & 15,3 & 36,0 & 23,5 & 11,0 & 15,3 & 36,0 & - & - & - & - \\
\hline MG & 1 & 14,0 * & $*$ & $*$ & $*$ & - & - & - & - & $14,0^{*}$ & $*$ & $*$ & $*$ \\
\hline MS & 5 & 14,3 & 12,4 & 0,1 & 30,7 & 16,2 & 12,9 & 5,8 & 30,7 & 9,5 & 11,7 & 0,1 & 22,5 \\
\hline MT & 6 & 28,9 & 5,7 & 20,2 & 35,3 & $24,1^{*}$ & $*$ & $*$ & $*$ & 29,8 & 5,8 & 20,2 & 35,3 \\
\hline PA & 1 & $17,7^{*}$ & $*$ & $*$ & $*$ & - & - & - & - & $17,7^{*}$ & $*$ & $*$ & $*$ \\
\hline PB & 1 & $40,2^{*}$ & $*$ & $*$ & $*$ & $40,2^{*}$ & $*$ & $*$ & $*$ & - & - & - & - \\
\hline PR & 1 & $9,5^{*}$ & $*$ & $*$ & $*$ & $9,5^{*}$ & $*$ & $*$ & $*$ & - & - & - & - \\
\hline RJ & 7 & 24,0 & 13,2 & 5,1 & 45,2 & - & - & - & - & 24,0 & 13,2 & 5,1 & 45,2 \\
\hline $\mathrm{RN}$ & 1 & $1,6^{*}$ & * & * & $*$ & $1,6^{*}$ & $*$ & * & $*$ & - & - & - & - \\
\hline $\mathrm{RO} / \mathrm{AC}$ & 2 & 7,2 & 9,0 & 0,9 & 13,6 & $0,9 *$ & $*$ & * & * & $13,6^{*}$ & $*$ & $*$ & * \\
\hline RR & 1 & $7,4^{*}$ & * & * & * & - & - & - & - & $7,4^{*}$ & $*$ & * & * \\
\hline RS & 3 & $12,2^{*}$ & * & * & * & $12,2^{*}$ & * & * & * & - & - & - & - \\
\hline SC & 3 & 17,5 & 5,5 & 11,2 & 21,3 & 17,5 & 5,5 & 11,2 & 21,3 & - & - & - & - \\
\hline то & 7 & 15,1 & 11,5 & 0,1 & 30,6 & 14,4 & 12,4 & 0,1 & 30,6 & $19,6^{*}$ & * & * & * \\
\hline Total & 91 & 13,7 & 11,0 & 0,0 & 45,2 & 11,7 & 10,6 & 0,0 & 40,2 & 17,5 & 10,8 & 0,0 & 45,2 \\
\hline
\end{tabular}

Fonte: elaboração própria.

Nota: *Apenas 1 edital disponível para análise.

Analisando os descontos ofertados em licitações pela LGL, Lima (2010) observou, em sua pesquisa, que a tendência de desconto para as obras de construção do DNIT se mantinha na média de 5\%. A Tabela 02 demonstra os descontos calculados para a amostra, 
e nota-se que os descontos referentes ao RDC aumentaram em média até 2,74 vezes em relação aos ofertados nos editais pela LGL da amostra de Lima (2010).

Lima (2010) também encontrou em sua pesquisa o desconto médio de 11,4\% para as construções orçadas em até 30 milhões, e de apenas 2,9\% para um desconto médio para as obras orçadas acima de 30 milhões. O mesmo não ocorre nas licitações de RDC analisadas, nestas verificou-se que não houve uma correlação entre o valor orçado pela administração e o desconto ofertado.

Através da Figura 01, nos casos em que na mesma unidade gestora há editais de orçamento sigiloso e não sigiloso, constata-se que a média de descontos são maiores nos casos em que os orçamentos não são sigilosos, fato que pode estar relacionado ao risco do licitante de realizar seu orçamento tendo como referência somente quantitativos e um anteprojeto, e sem saber o valor orçado pela administração.

Figura 01 | Média do desconto em RDCs por unidade gestora do DNIT (2015 - 2017)

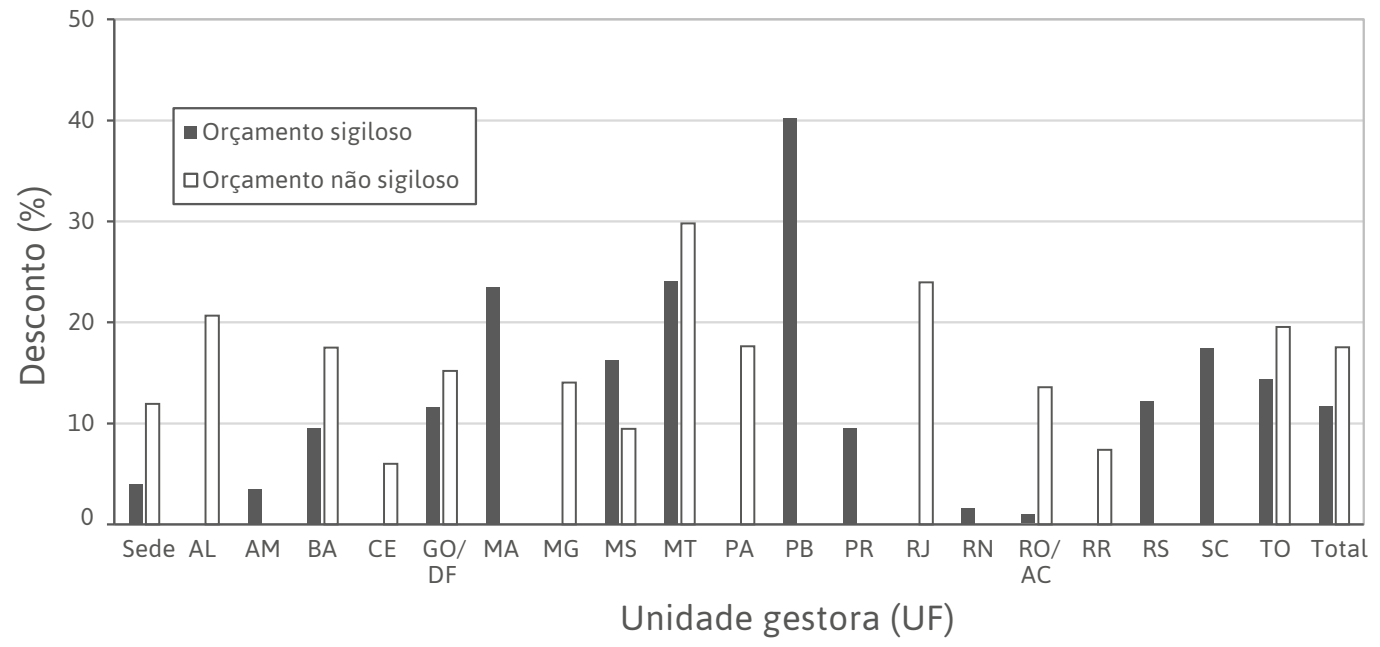

Fonte: elaboração própria.

\subsection{Número de concorrentes}

O número médio de concorrentes da amostra em estudo é em torno de 10 para os editais de orçamento não sigiloso e de 8 para os de orçamento sigiloso, resultando em 
uma diferença de $20 \%$. Apesar de ambos serem considerados com dispersão muito alta, conforme classificação de Pimentel-Gomes (2009), o número de concorrentes para os editais com orçamento não sigiloso é em torno de $40 \%$ mais disperso do que na situação sigilosa. O risco por participar de uma licitação em que o orçamento é sigiloso pode ser pelo fato de se ter um número menor de participantes e menos dispersos.

Assim como a CGU (2017) concluiu, também se constatou uma correlação entre o desconto ofertado e o número de licitantes, como se pode verificar no gráfico da Figura 02. Essa correlação foi verificada através do coeficiente de Pearson ( $r$ ), que, por definição, segundo Figueiredo Filho e Silva Junior (2009), é uma medida de associação linear entre variáveis, que ocorre quando as variáveis mantêm a medida da variância compartilhadas entre si. A correlação pode ser considerada moderada, conforme os mesmos autores, com valores de coeficiente $(r)$ de 0,53 e 0,55 , respectivamente para os editais de orçamento sigiloso e orçamento não sigiloso.

Em licitações regidas pela LGL, essa relação também foi confirmada por Lima (2010), que apurou que mais da metade das licitações que tiveram de 1 a 6 concorrentes não obtiveram sequer $5 \%$ de desconto, entretanto, mais da metade das licitações com 8 ou mais concorrentes alcançaram mais de $30 \%$ de desconto.

Figura 02 | Relação entre o desconto e o número de concorrentes

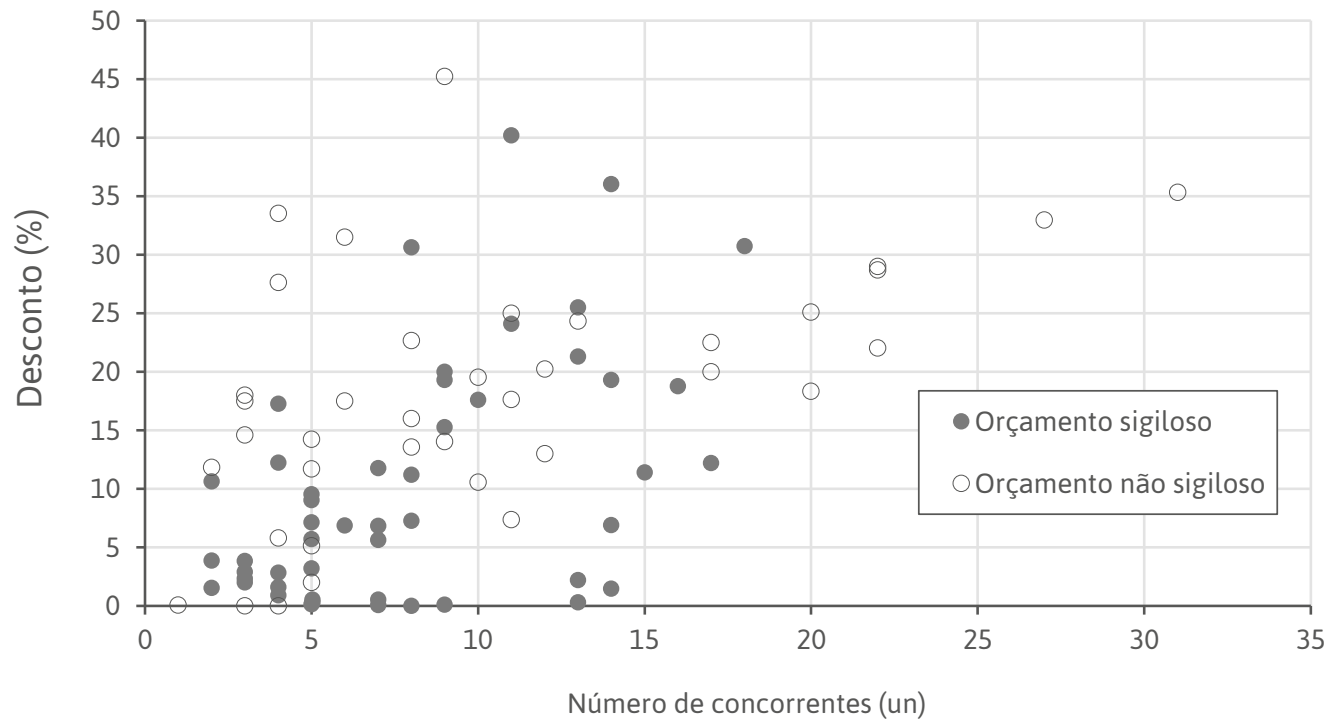

Fonte: elaboração própria. 
Devido à variação dos valores de orçamento das obras estudadas, o que caracteriza o porte da obra, plotaram-se os valores dos orçamentos disponibilizados pela administração para os editais da amostra de RDC de orçamento sigiloso e não sigiloso, e os respectivos números de concorrentes que participaram da licitação, o que resultou no gráfico da Figura 03.

Figura 03 | Relação entre o valor orçado pela administração e o número de concorrentes

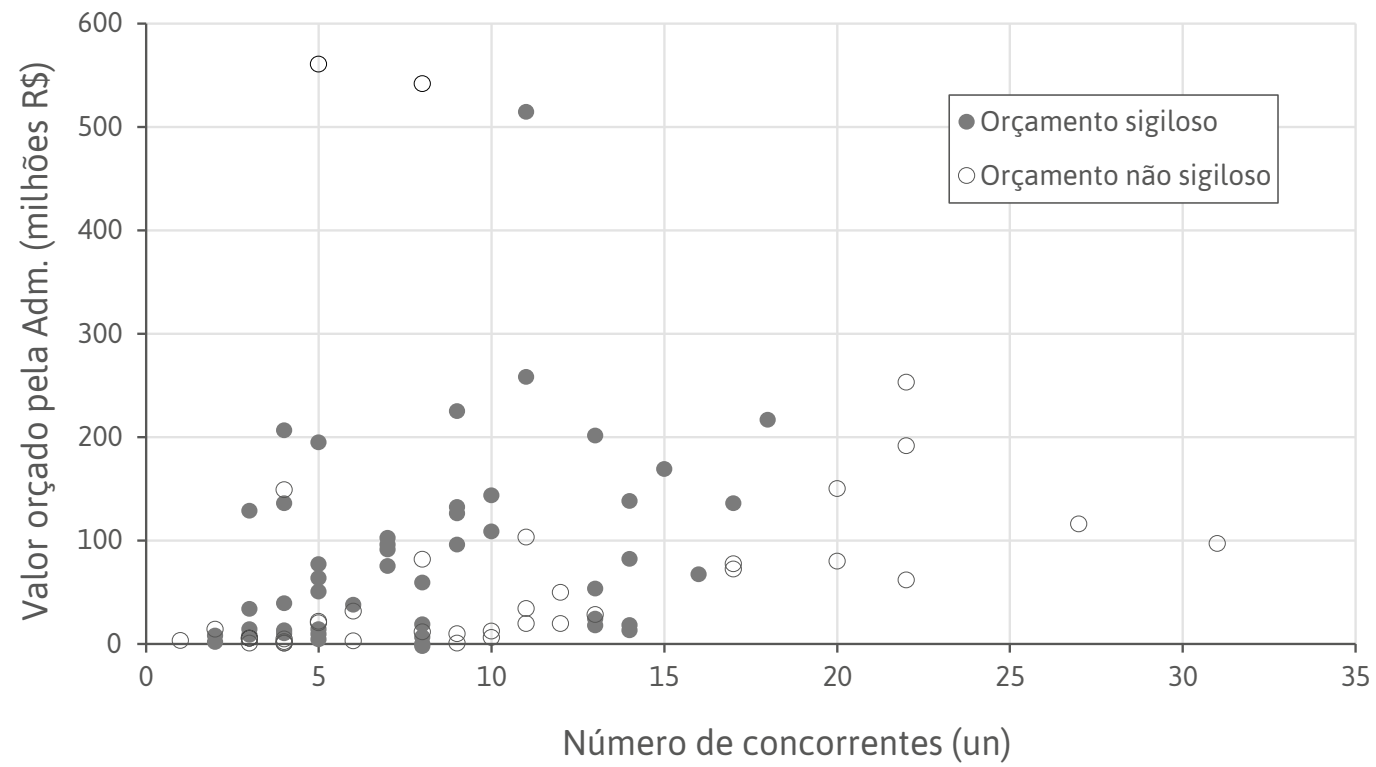

Fonte: elaboração própria.

Verificou-se, quanto à correlação linear das variáveis, valores de $r$ iguais a 0,34 e 0,22, para os orçamentos sigilosos e não sigilosos, respectivamente. Pode se considerar essas correlações fracas e até desprezíveis, conforme Figueiredo Filho e Silva Junior (2009). Tanto o gráfico da Figura 02 quanto o da Figura 03 demonstram que o maior número de concorrentes se encontra entre os editais com orçamento não sigiloso.

A maior parte dos editais são referentes a obras orçadas em até 300 milhões, e nessa faixa de valor o máximo de concorrentes a participar quando os editais eram de orçamento sigiloso foi 18 , entretanto, quando o orçamento não era sigiloso, ocorreu licitação com até 31 concorrentes. Observou-se que, nos três editais com orçamento entre 500 - 600 milhões, demonstrados na Figura 03, o número de concorrentes reduziu, variando entre 5 e 11, sendo a relação do número de concorrentes e o valor do edital inversamente proporcional. 
Refletindo sobre a competividade no cenário das licitações pela LGL, recorrese a Lima (2010), que constatou que em licitações de construções do DNIT, a variação no número de concorrentes ficou no intervalo de 1 a 11 , e as obras de maior porte não permitiam muita competividade.

No trabalho realizado pela CGU (2017), os editais de RDC do DNIT pelo regime de contratação integrada no período de 2012 - 2014, o número médio de participantes para as licitações de forma eletrônica era em torno de 5 . Considerando que todos os editais dessa pesquisa foram realizados de forma eletrônica, verifica-se que esse valor médio passou a ser 8 , resultando num acréscimo de $60 \%$ no número de concorrentes. Esse aumento da competitividade nas licitações dos últimos três anos pode ter sido reflexo da redução do orçamento da área de transportes divulgado nos relatórios DNIT (2015; 2016), que, consequentemente, reduziu drasticamente o número de licitações do órgão. A experiência adquirida pelo DNIT com a modalidade do RDC também pode ter atraído mais concorrentes, tendo em vista que a referência temporal da pesquisa da CGU (2017) se refere à fase inicial pela adoção ao novo regime.

Reunindo os dados médios da amostra e os encontrados na revisão bibliográfica, como demostrado na Tabela 03, nota-se uma maior dispersão nos prazos, e esse comportamento pode receber influência do tamanho da amostra, do período referencial, da demanda e preparo da unidade do DNIT responsável pelo processo licitatório e da predominância do tipo de obra ou serviço nos objetos dos editais, fatores que devem ser considerados, ao se analisar os dados de prazo de licitações do DNIT, na escolha da modalidade do certame. 
Tabela 03 | Resumo dos dados

\begin{tabular}{|c|c|c|c|c|c|c|}
\hline \multirow{2}{*}{ Referências } & \multicolumn{2}{|c|}{$\begin{array}{l}\text { Prazos médios* } \\
\text { (dias) }\end{array}$} & \multicolumn{2}{|c|}{$\begin{array}{c}\text { Descontos médios } \\
\text { (\%) }\end{array}$} & \multicolumn{2}{|c|}{$\begin{array}{l}\mathrm{n}^{\circ} \text { médio de } \\
\text { participantes }\end{array}$} \\
\hline & LGL & RDC & LGL & RDC & LGL & RDC \\
\hline CGU (2017) & - & 137 & - & 9,18 & - & 5,23 \\
\hline Breyer (2013) & 126 & 90 & - & - & - & - \\
\hline $\begin{array}{l}\text { Branco Junior } \\
\text { (2013) }\end{array}$ & 180 & $138-147$ & 10,1 & $13,5-2,9$ & - & - \\
\hline Lima (2010) & - & - & $\begin{array}{c}11,4- \\
2,9\end{array}$ & - & $1-11$ & - \\
\hline $\begin{array}{l}\text { Dados } \\
\text { analisados } \\
(2015-2017)\end{array}$ & - & $113^{* *}$ & - & 13,7 & - & $8-10$ \\
\hline
\end{tabular}

Fonte: elaboração própria.

Notas: *inicia na publicação do edital até a sua homologação.

**soma da média de 78 dias obtida acrescido ao prazo de 35 dias encontrados por Rosinha (2013) referente ao prazo entre a publicação do edital e a data de apresentação dos valores ofertados pelos licitantes.

\section{Conclusão}

A pesquisa demonstrou que os editais de RDC do DNIT, no período entre 2015 e 2017, são, em maioria, na modalidade de contratação integrada. Não obstante, a maioria desses detém orçamento sigiloso, e todos foram licitados no formato eletrônico. Mesmo a autarquia aplicando essa modalidade desde 2012, não significa que esteja sendo usada de forma eficiente pelo órgão, o que amplia a relevância do presente estudo. 
Observa-se que o benefício no RDC, demonstrado nesta pesquisa, em relação à redução do período de licitação, pode estar sendo anulado por deficiências na gestão dos processos, como, por exemplo: na fase dos atos preparatórios à elaboração dos editais, nos termos de referência e anteprojetos e, ainda, na capacitação e experiência da equipe responsável pela operação do processo. Isso explicaria as ocorrências com baixa redução média do prazo total do processo licitatório, e o período adicional desnecessário entre a publicação do edital no Diário Oficial da União e a data de recebimento das propostas, o qual, em média, supera o mínimo que a legislação exige. Situações que obrigam a retroceder fases, tais como erratas de edital, suspensão e reabertura, impugnações e cumprimento de determinações judiciais, interferem no prazo total da licitação.

Constatou-se que os descontos médios no RDC, quando comparados às licitações regidas pela LGL, tiveram uma significativa melhora, quando os orçamentos não são sigilosos. A forma eletrônica do RDC, que evita o contato entre os concorrentes, diminui a possibilidade de conluio, o que pode ser um dos fatores responsáveis por esse aumento de desconto. A preocupação das empresas em se manterem ativas com contratos, perante uma queda de investimentos no setor, também pode estar relacionada ao aumento de desconto. No caso dos orçamentos sigilosos onde os descontos são menores, esse evento pode estar relacionado ao maior risco inerente a esse tipo de licitação.

Quanto ao número de concorrentes observados na amostra de RDC, verificou-se que há correlação linear com os descontos ofertados, convergindo, dessa forma, com a bibliografia existente tanto para os editais de RDC quanto os que seguem a LGL. Os editais com orçamentos não sigilosos são os que atraíram o maior número de concorrentes. Averiguou-se que, em média, o número de participantes nas licitações de RDC, nos últimos três anos, aumentou quando comparado às licitações oriundas da LGL e de RDC em período anterior. Esse evento pode ter explicação na falta de oferta dos órgãos públicos oriunda da contenção de recursos e, ainda, num possível amadurecimento do know-how do DNIT na aplicação do RDC.

Conclui-se que não há correlação linear entre o valor da obra e o número de concorrentes nos editais de RDC analisados, comportamento contrário ao observado nas licitações amparadas pela LGL, conforme a bibliografia disponível. A presença majoritária de editais com orçamento sigiloso pode ter influência nessa mudança de comportamento, 
pois o valor da obra que podia ser um atrativo não é divulgado, ficando a cargo do licitante elaborar seu orçamento, assumindo riscos.

Nota-se que existem muitas externalidades que podem influenciar a eficiência das licitações num RDC, como a disponibilidade de recursos, além de fatores intrínsecos como a forma eletrônica, o orçamento sigiloso, a qualificação do recurso humano envolvido na licitação, a qualidade dos termos de referência e anteprojetos, os quais devem ser observados na análise dos resultados. Finalmente, é possível identificar que a aplicação do RDC pode melhorar a eficiência dos processos licitatórios regidos pela LGL, visto que reduzem o tempo médio de licitação e aumentam o desconto ofertado.

As informações adquiridas com a pesquisa podem servir como referência para agentes políticos nas alterações futuras da legislação de licitações que possam tornar o RDC uma modalidade a ser utilizada de forma indiscriminada, e no aprimoramento de suas regras, tornando-o mais ágil e mais competitivo. A compilação dos prazos que cada unidade do DNIT está praticando para realizar as licitações de RDC pode servir como parâmetro aos gestores no dimensionamento das equipes envolvidas no processo.

O período da pesquisa foi um fator limitador devido ao tamanho da população de editais de RDC do DNIT, e então se optou por um período ausente na pesquisa bibliográfica e mais atual. Contudo, ainda cabe explorar as vantagens e desvantagens providas pelo RDC, considerando sua aplicação recente comparada aos 25 anos da LGL. Sugere-se a continuidade da pesquisa para os anos futuros, bem como relacionar a experiência e capacitação dos servidores públicos envolvidos com as licitações, com os prazos por eles praticados durante os respectivos processos. O desenvolvimento de pesquisas futuras em contratos provenientes das licitações de RDC, quanto ao cumprimento de cronograma e aditivos realizados, principalmente na contratação integrada, complementaria a avaliação quanto à eficiência do novo regime. 


\section{Referências bibliográficas}

BAETA, A.P. Regime Diferenciado de Contratações Públicas: aplicado às licitações e contratos de obras públicas. São Paulo: Editora Pini, 2013.

Bergue, S.T. Cultura e Mudança Organizacional. Curso de Especialização em Gestão Pública. Florianópolis: Departamento de Ciência da Administração/UFSC; [Brasília]: Capes: UAB, 2010. 106p. Apostila da disciplina Cultura e Mudança Organizacional.

BRANCo JUnIOR, A. S. Comparativo entre o Regime Diferenciado de Contratações - RDC e a Lei $n^{\circ}$ 8.666/93, estudo de caso: contratações de obras de Engenharia pelo DNIT e Infraero. 2013. 57p. Monografia (Graduação em Ciências Contábeis) - Universidade de Brasília, Brasília, 2013. Disponível em: <http://bdm.unb.br/handle/10483/13864>. Acesso em: 13 mar. 2018.

Brasil. Constituição de 1988. Constituição da República Federativa do Brasil. Diário Oficial da União, Brasília, DF, 05 out. 1988. Disponível em: <http://www2.camara.leg.br/legin/fed/ consti/1988/constituicao-1988-5-outubro-1988-322142-publicacaooriginal-1-pl.html>. Acesso em: 29 mar. 2018.

Decreto no 7.581, de 11 de outubro de 2011. Regulamenta o Regime Diferenciado de Contratações Públicas - RDC, de que trata a Lei $n^{\circ}$ 12.462, de 4 de agosto de 2011. Diário Oficial da União, Brasília, DF, 13 out. 2011, 2011a. Disponível em: <http://www.planalto.gov.br/ ccivil_03/_ato2011-2014/2011/decreto/d7581.htm>. Acesso: 29 mar. 2018.

. Lei no 12.462, de 04 de agosto de 2011. Institui o Regime Diferenciado de Contratações - RDC... Diário Oficial da União, Brasília, DF, 05 ago. 2011, 2011b. Disponível em: <http://www. planalto.gov.br/ccivil_03/_ato2011-2014/2011/Lei/L12462.htm>. Acesso em: 29 mar. 2018.

Lei no 10.520, de 17 de julho de 2002. Institui no âmbito da União, Distrito Federal, estado e municípios, nos termos do art. 37, inciso XXI, da Constituição Federal, modalidade de licitação denominada pregão, para a aquisição de bens e serviços comuns, e dá outras providências. Diário Oficial da União, Brasília, DF, 18 jul. 2002. Disponível em: <http://www. planalto.gov.br/ccivil_03/Leis/2002/L10520.htm>. Acesso em: 29 mar. 2018.

. Lei no 11.079 , de 30 de dezembro de 2004. Institui normas gerais para licitação e contratação de parceria público-privada no âmbito da administração pública. Diário Oficial da União, Brasília, DF, 31 dez. 2004. Disponível em: <http://www.planalto.gov.br/ccivil_03/_ato20042006/2004/lei/l11079.htm>. Acesso: 29 mar. 2018.

. Lei no 8.666, de 21 de junho de 1993. Regulamenta o art. 37, inciso XXI, da Constituição Federal, institui normas para licitações e contratos da administração pública e dá outras providências. Diário Oficial da União, Brasília, DF, 22 jun. 1993. Disponível em: <http://www. planalto.gov.br/ccivil_03/Leis/l8666cons.htm>. Acesso em: 21 out. 2016.

. Lei no 8.987, de 13 de fevereiro 1995. Dispõe sobre o regime de concessão e permissão da prestação de serviços públicos previsto no art. 175 da Constituição Federal, e dá outras providências. Diário Oficial da União, Brasília, DF, 14 fev. 1995. Disponível em: <http://www. planalto.gov.br/ccivil_03/Leis/L8987cons.htm>. Acesso: 29 mar. 2018. 
Tribunal de Contas da União. Processo no TC 033.102/2015-5. Acórdão 306/2017 Plenário de 22 fev. 2017. Disponível em: <https://contas.tcu.gov.br/c?seAbrirDocNoBrowser=true \&codArqCatalogado=11913253\&codPapelTramitavel=56464400>. Acesso em: 29 mar. 2018.

BREYER, A. Eficiência no processo licitatório de obras rodoviárias licitadas através do Regime Diferenciado de Contratações Públicas - RDC. 2013. 37p. Monografia (Especialização em Gerenciamento de Obras) - Universidade Tecnológica Federal do Paraná, Curitiba, 2013. Disponívelem: <http://repositorio.roca.utfpr.edu.br/jspui/handle/1/2706>. Acesso em: 15 mar. 2018.

CALDEIRA, D.M. et al. Análise do gerenciamento de riscos em contratos de obras públicas pela elaboração de matrizes de maturidade. Revista Espacios, Caracas, v. 38, n. 47, p. 27 - 38, 2017. Disponível em: <http://www.revistaespacios.com/indice.html>. Acesso em: 15 mar. 2018. ISSN: 0798-1015.

CELESTINO, F.K.R. Regime Diferenciado de Contratações: breves comentários à execução que virou tendência. Revista Controle, Ceará, v.10, n. 2. p. 170 - 201, jul/dez, 2012. Disponível em: <https:// www.tce.ce.gov.br/edicoes/revista-controle-volume-x-n-2-jul-dez-2012>. Acesso em: 13 mar. 2018. ISSN 1980-086X.

CONTROLAdORIA GeRAL DA UnIÃo (CGU) - Ministério da Transparência, Fiscalização e Controladoria Geral da União. Relatório de Auditoria OS: 201505075. Avaliação dos resultados da adoção do Regime Diferenciado de Contratação - RDC, com ênfase no regime de contratação integrada no DNIT. Brasília, 2017. Disponível em: <http://www.cgu.gov.br/assuntos/auditoria-e-fiscalizacao/ pesquisa-de-relatorios/relatorios-em-destaque/2017/01/boletim-no-21-09-01-a-20-01>. Acesso em: 13 ago. 2017.

CORRALO, G.; CARDOSO, B.L. Os reflexos da reforma gerencial no regime diferenciado de contratações públicas: a implementação do mecanismo da remuneração variável. Constituição, Economia e Desenvolvimento: Revista da Academia Brasileira de Direito Constitucional. Curitiba, v. 7, n. 13, p. 564-585, jul./ dez. 2015. Disponível em: <http://www.abdconst.com.br/revistas.php>. Acesso em: 20 out. 2016. ISSN 2177-8256. DOI 10.24068/2177.8256.2015.7.13;564.585.

Dal Pozzo, A.N. Panorama Geral dos Regimes de Execução Previstos no Regime Diferenciado de Contratações: A Contração Integrada e seus Reflexos. Coordenadores: Márcio Cammarosano, Augusto Neves Dal Pozzo, Rafael Valim. Belo Horizonte: Fórum, 2012.

DEPARTAMENTO NACIONAL DE INFRAESTRUTURA DE TRANSPORTES (DNIT). Institucional. Última alteração 22 fev. 2017. Disponível em: <http://www.dnit.gov.br/acesso-a-informacao/ insitucional>. Acesso em: 04 maio 2018.

Relatório de Gestão do Exercício de 2012. Diretoria de Planejamento e Pesquisa. Disponível em: <http://www.dnit.gov.br/acesso-a-informacao/relatorio-de-gestao>. Acesso em: 02 maio 2018.

Relatório de Gestão do Exercício de 2015. Diretoria de Planejamento e Pesquisa. Disponível em: <http://www.dnit.gov.br/acesso-a-informacao/relatorio-de-gestao/relatorio-degestao-2015>. Acesso em: 02 maio 2018. 
Relatório de Gestão do Exercício de 2016. Diretoria de Planejamento e Pesquisa.

Disponível em: <http://www.dnit.gov.br/acesso-a-informacao/relatorio-de-gestao/relatorio-degestao-2016-1/relatorio-de-gestao-2016>. Acesso em: 02 maio 2018.

FIgUeIREDo FILHO, D.B.; SILVA JúNIOR, J.A. Desvendando os mistérios do coeficiente de correlação de Pearson (r). Revista Política Hoje, v. 18, n. 1, p. 115 - 146, 2009.

LIMA, M.C. Comparação de custos referenciais do DNIT e licitações bemsucedidas. In: Simpósio Nacional de Auditoria de Obras Públicas, XIII, 2010, Porto Alegre, Anais, Florianópolis, IBRAOP, 2010. Disponível em: <http://www.ibraop.org.br/blog/artigos/xiii-sinaop-i-oficina-internacionalporto-alegrers/>. Acesso em: 13 ago. 2017.

Lolı, D.A.; Mello, G.R.; Rojo, C.A. Regime Diferenciado de Contratações e Concorrência Pública: um estudo sob a ótica da economicidade. RACE, Joaçaba, v. 16, n.1,p.37-64,jan./abr.2017. Disponível em: <http://editora.unoesc.edu.br/index.php/race>. Acesso em: 13 mar. 2018. E-ISSN 2179-4936.

Malmegrin, M.L. Gestão Operacional. Curso de Especialização em Gestão Pública. Florianópolis: Departamento de Ciência da Administração/UFSC; [Brasília]: Capes: UAB, 2010. 200p. Apostila da disciplina de Gestão Operacional.

OLIVEIRA, R.C.R.; FreITAS, R.V. O regime diferenciado de contratações públicas (RDC) e a administração de resultados. REDAE - Revista Eletrônica de Direito Administrativo Econômico. Salvador, n. 27, ago./set./out. 2011. Disponível em: <http://www.direitodoestado.com.br/redae/ edicao/27>. Acesso em: 20 out. 2016. ISSN 1981-1861.

PAIM, J.V.A. Regime diferenciado de contratações: uma análise de contratos em uma empresa pública. 2015, 110p. Dissertação (Mestrado em Ciências Contábeis). Universidade Federal de Minas Gerais, Belo Horizonte, 2015.

PIMENTEl-Gomes, F. Curso de estatística experimental. 15a edição. Piracicaba: Fealq, 451 p.,2009.

RODRIGUES, A.C.G. A contratação integrada no regime diferenciado de contratações públicas. 2016. 157p. Dissertação (Mestrado em Direito - área de concentração: Direito Administrativo) Pontifícia Universidade Católica São Paulo, 2016. Disponível em: <https://tede2.pucsp.br/handle/ handle/18847>. Acesso em: 20 out. 2016.

RosınHA, R.F. Contratações Públicas: o Regime Diferenciado de Contratações Públicas (RDC) como uma alternativa à Lei Geral de Licitações e Contratos. 2013. 38p. Trabalho de conclusão de curso (artigo -graduação). Departamento de Ciências Contábeis e Atuariais da Faculdade de Economia, Administração e Contabilidade da Universidade de Brasília, Brasília, 2013. Disponível: <http://bdm. unb.br/handle/10483/12557>. Acesso em: 20 out. 2016. 


\section{Karine da Rocha Alves}

(iD) https://orcid.org/0000-0001-5919-3458

Engenheira Civil. Mestre em Engenharia pela Universidade Federal do Rio Grande do Sul. Especialista em Gestão Pública pela Universidade Federal de Santa Maria. Analista em Infraestrutura de Transportes do Departamento Nacional de Infraestrutura de Transportes

$@$ karine. alves@dnit.gov.br

\section{Taís de Andrade}

(iD) https://orcid.org/0000-0001-7870-6909

Administradora. Mestre em Administração pela Universidade Federal de Santa Maria. Doutora em Administração pela Universidade Federal de Santa Maria. Professora da Universidade Federal de Santa Maria tais0206@gmail.com

\section{Luciano Moises Sippert Santarem}

(iD) https://orcid.org/0000-0003-1222-4098

Engenheiro Civil. Mestre em Avaliação de Impactos Ambientais pela Universidade La Salle. Especialista em Gestão Pública pela Universidade Federal de Santa Maria. Analista em Infraestrutura de Transportes do Departamento Nacional de Infraestrutura de Transportes

@luciano.santarem@dnit.gov.br 